\title{
Foreword
}

\section{Tragedy and Triumph: The Life and Legacy of Am Yisrael}

\author{
Rabbi Stewart M. Weiss
}

Jewish life-it cannot be disputed nor avoided-is a mystical mixture of tragedy and triumph. These two physical and emotional poles of the human experience travel with us wherever we sojourn, and they form the backdrop for history's most compelling human story. Biblical heroes Avraham, Sarah and Yitzchak, despite their prominence on the world stage, had their Akeida to grapple with, while Yakov faced innumerable challenges throughout his own life, including the death of his beloved wife Rachel, the kidnapping and assumed death of his favorite son Yosef, and his descent into the depravity of Egypt.

Moshe, for his part, was not afraid to confront God regarding divine justice. He asked of Hashem, "Hareini-na et k'vodecha" (Show me Your glory), which the rabbis interpret as inquiring why Bnei Yisrael had to suffer so greatly before their eventual liberation.

Although at first glance this appears to be Moshe throwing up his hands in resignation, the rabbis interpret this statement very differently. Moshe, as the truest prophet, understood that he would not be the ultimate Redeemer. While he would indeed liberate the Israelites from Egypt, that would mark only the beginning of our struggle, not the end. We would go on to suffer countless catastrophes, such as expulsions from our Holy Land at the hands of the Babylonians and the Romans, pogroms, inquisitions, and the Holocaust. So, Moshe-ever the great defense attorney of the people of 
xii $\mid$ Foreword

Israel-argued passionately to the Almighty: "Please, God, send the final Goel now. Spare my people this endless parade of misfortunes!"

But Hashem was emphatic in His denial of Moshe's request, for the history of our nation is not one-dimensional; it is not limited exclusively to success and salvation. It is a series of both great victories and frightening dangers, a cosmic combination of the highest highs and the lowest lows. It is not a pattern that we would choose, perhaps, but it is ours to contend with nonetheless, until our final Geula.

The secret to Jewish survival, I contend, is two-fold: We must steel ourselves to somehow endure the pain and suffering we encounter-both as individuals and as a people; and we must discover how to turn the dark days into light, distilling hope and glory out of our deepest despair. Even at the very lowest moments in our lives, we must claw our way back to normalcy, back to our elite status as God's chosen first-born, reviving and rejuvenating our faith in both God and ourselves. And we must train ourselves to see God's hand in all things, acknowledging a higher plan and ultimate justice, despite that which we consider irredeemably unjust.

When Aaron the Kohen Gadol's sons Nadav and Avihu die, the Torah records his reaction as "Vayidom Aharon"-Aaron was paralyzed, speechless, immobile. Most readers would assume that Aaron was simply too grief-stricken to respond. But Rabbi Moshe Feinstein offers a striking viewpoint. Nadav and Avihu, he says, were tzadikim, righteous peopleindeed, even Moshe tells his brother, "They are more righteous than you and I!" But they overstepped their boundaries in a passionate desire to draw closer to Hashem, and they were taken. Aaron thus is caught between two diametrically opposed emotions. On the one hand, he is overwhelmed with sadness at the loss of his eldest sons, his heirs apparent. Yet at the same time, he is sent a vision that in the halls of Heaven, the angels are giving the grandest of welcomes to these two extraordinary individuals who have earned their exalted place in Gan Eden. And so, not knowing whether to cry out in pain or sing out in joy, Aaron does the only thing he can do he remains silent.

My wife Susie and I can fully relate to this scenario. Our eldest son, staff Sgt. Ari Yehoshua, served as a member of the IDF's Sayeret Nachal elite anti-terror unit. He was involved in countless dangerous missions during the second intifada. When his unit captured Hamas headquarters in Shechem (Nablus) in 2002, he was killed in a firefight between the Israeli 
army and the terrorists. He died while helping to save the life of a fellow soldier.

And so, while Susie and I mourn Ari's death every day of our lives, we also feel immense pride in his stature as a true hero of Israel and the Jewish People. His courage and ultimate self-sacrifice grant him an eternal place in the annals of our nation's epic struggle, and we stand in awe of his strength and stature.

Some years ago, I told the stirring story, in my column in The Jerusalem Post, of Chaim and Baruch Shapiro, a story that would ironically become our own personal narrative. Chaim had survived four concentration camps. During the Shoa, he lost his wife and seven of his children, without having the chance to even sit shiva for them. He was finally liberated from Buchenwald with his only surviving son, Baruch. They spent three years in a DP camp until finally, in 1948, they found place aboard an immigrant ship and came to Israel.

They landed in the midst of the War of Independence, with the fledgling nation fighting a desperate battle for survival against overwhelming odds. So, Baruch volunteered to fight. With no previous training, he was handed a rifle, taught how to shoot, and was sent off to war. Baruch distinguished himself in battle as part of the Harel Brigade, fighting to break the Arab siege of Jerusalem. He was even awarded a medal for bravery under fire.

Then, one day, Chaim received the bitter news that his son had been killed in battle. Chaim had only one request: he wanted his son to be buried in Jerusalem, on Mount Herzl, the national military cemetery. The next afternoon, hundreds of mourners gathered at Mount Herzl. Most of them had never known Baruch or his father, but they had heard of the tragedy and wanted to pay their respects. After all, what Hitler had not finished in the crematoria had ended with an Arab bullet. This was the last Shapiro son, the end of a line. Yigal Yadin, the IDF chief of staff, stood by Chaim Shapiro's side during the funeral.

As Baruch's coffin was being lowered into the ground, Chaim began to sing. People thought he had gone crazy from grief and tried to quiet him, but he shrugged them all off and continued singing. Finally, Chaim spoke:

I have been through a hell the likes of which most people cannot imagine. I lost over 70 relatives in a little over a year, including seven children, my wife, and my parents. I have no place to mourn them, no grave. They are ashes in the skies over Europe, and I have no idea why they had to die. But this son, I 
xiv $\mid$ Foreword

do know why he died. He died in glory, fighting as a proud soldier on behalf of the entire Jewish People, in defense of our own precious land and the State of Israel. His grave is not unmarked; it is in a place of honor on Mount Herzl in Jerusalem. And that is not a reason to cry, it is a reason to sing.

When Chaim finished speaking, he began to sing once again and to grab people's hands to dance. And so, as Baruch's flag-draped coffin was lowered into the ground, 300 mourners sang and danced against the setting sun of the Jerusalem sky.

Baruch and Chaim Shapiro's story is the story of our nation, our history. We undergo fierce trials, we are bloodied and wounded, but somehow, we survive. In fact, we flourish. We are the most resilient, determined and indestructible of any people to ever walk this Earth.

Am Yisrael chai.

Rabbi Weiss was educated at the Beit Midrash L'Torah (Hebrew Theological College) in Skokie, Illinois, where he received his degrees in Hebrew literature and rabbinical studies. He served as the rabbi of congregations in Chicago and Dallas and was head Jewish chaplain at Rush Medical Center in Chicago. He made aliya in 1992 and lives in Rainana, where he directs the Jewish Outreach Center. He is a regular columnist for The Jerusalem Post and lectures frequently in Israel, the US, England, and South Africa. 